\section{Learning to Learn the Nursing Consultation: Comprehensive Analysis in the Perspective of the Student}

\title{
Abstract
}

This is a qualitative study of a descriptive nature with an approach in the sociological phenomenology of Alfred Schutz. Twenty students participated. They were from the Undergraduate Nursing Course of a School in the Serrana Region - RJ, Brazil. Data collection was carried out from April to June 2015, after approval by the Ethics and Research Committee, according to opinion 874.087. Objectives: To describe the students' learning about the Nursing Consultation Action; to understand the meaning of the Nursing Consultation Assistance Action learning by the students who undertook the supervised internship in the Basic Care Network. For the data collection, a phenomenological interview was performed. The discourse of the students resulted in four categories: Category 1: Using learning theory and practice in Nursing Consultation; Category 2: Learning how to learn about nurses' assignments; Category 3: Building the learning process with satisfaction and Category 4: Learning to learn the Social Action of the nurse to resolve. The answers obtained by the students contributed to understanding the experience in the universe of learning the Social Action of the Nurse - Nursing Consultation. From then, it is possible to devise strategies of teaching and learning, in a way that contemplates the student, considering the singularity.

\section{Introduction}

The correlation of theoretical content with practical actions is part of the continuous process of learning in any profession. It is essential that nurses seek professional training throughout life, that is, the learning process needs to be continuous, aiming to develop different skills

Aline Furtado da Rosa', Ann Mary Machado Tinoco Feitosa Rosas ${ }^{2}$

1 Nurse. Master's degree in Nursing at the Anna Nery Nursing School/UFRJ. Coordinator of the Multiprofessional Residency Program in Basic Attention Network of Arthur Sá Earp Neto College and Petrópolis Municipal Secretary.

2 Nurse. PhD in Nursing at the Anna Nery Nursing School. Adjunct Professor IV of the Department of Nursing Teaching Methodology, Anna Nery School of Nursing/UFRJ.

\section{Contact information:}

Aline Furtado da Rosa.

”" alinenfermagem@yahoo.com.br

Keywords

Consultation; Nursing; Learning; Nursing Education. 
necessary to provide care to diverse populations throughout the life cycle [1].

By being able to correlate the theoretical content with the daily activities, the professional feels safe when planning and executing his assignments. "The integration of the theory and practice favors the self-esteem of the professionals who work in the assistance because they feel able to expose the anchoring of their actions" [2].

Nursing is a profession strengthened in its practical dimension. As an example, there is the Nursing Consultation Assistance Activity, which allows maintaining a retro channel that feeds the theoretical contents and the practical actions, because, knowledge is necessary for its accomplishment: semiology and semiotics, anatomy, physiology, microbiology, epidemiology, pathology, sociology, anthropology, communication, and others. "Practice is the basis for the development of nursing theory, having its roots in practice, being refined by research and reapplied in practice" [3].

Improving nursing care is a constant concern. The search for knowledge contributes to systematize and organize the care process, based on the biological dimension as well as on the understanding of the human being as a social subject in the state of health or disease, either in the hospital context or the collective health [4].

In this sense, when the nurse performs the Nursing Consultation, he has one of the assistance procedures that is based on theoretical principles, applied through the nursing process, allowing to understand that it is a private area of the nurse.

In Brazil, according to the Professional Exercise Law, which regulates and legitimates the Nursing Consultation, it is determined to be a private activity of the nurse; uses components of the scientific method to identify health/disease situations, prescribe and implement nursing measures that contribute to the promotion, prevention, protection of health, recovery and rehabilitation of the individual, family and community. It further states that it is based on the principles of universality, equity, resolution and integrality of health actions [5].

During the Nursing Consultation, the nurse is responsible for enabling quality to the life of the patient; he is concerned with providing answers to the problems identified through the diagnoses that can propose resolutive actions with an effective strategy for the early detection of health deviations, and he can be performed when the individual and/or community presents no problems, since the Nursing Consultation acts in the promotion of health and transformation of social reality. From the perspective of the sociological phenomenology of Alfred Schutz, nursing care can be considered as Social Action that sets the world of life" [6].

Thus, in a face-to-face relationship, during his Social Action the nurse shows the how he cares about the assisted community. "The Nursing Consultation enables the work of the nurse during patient care, facilitating the identification of problems and the decisions to be made" [7].

In this sense, Rosas [8] shows the following definition of Nursing Consultation:

The Nursing Consultation can be carried out in several settings such as communities, households, industries, public health units, schools, nurseries, outpatient clinics, hospitals and many others, the provision of nursing care through the Nursing Consultation, not only to sick people, but it is also an activity that goes beyond meeting the basic human needs of the human being, aims at self-care, self-esteem, self-esteem, citizenship not only those who receive care but those who provide this care.

From this perspective, the Nursing Consultation validates and values the role of the nurses. The commitment is based on clear diagnoses based on the human biological needs of the individual to result in life-enhancing actions even if the response is not healed. 
It is worth noting that the Nursing Consultation does not occur in substitution of any other profession, so when it is not possible to respond to the patient's needs, one of the nursing interventions is to refer the patient to another professional who has a response to a certain demand, promoting multidisciplinary actions that aim to improve the lives of individuals and communities.

Araújo [9] in his study states that: "The nurse must work with the multi-disciplinary team to serve the patient holistically, referring him to other professionals, whenever necessary."

Thus, it is believed that the Nursing Consultative Assistance Action is timely for the development of the teaching and learning process, since the students in a face-to-face relationship with teachers share the theoretical contents acquired during the Graduation Course, with the applicability of this knowledge in the provision of healthcare for the individual and collective of all age groups.

Thus, according to Delors [10], the education must be based on four learning centers - the pillars of knowledge: learning to know, that is, having the means to understand; Learn to do to act on the environment; Learn to live together to participate and cooperate with others in all activities; and to learn to be, which allows to integrate the three previous pillars.

The co-responsibility of the learning process needs to happen together with teachers, students and professionals in the training of the professional who will work in the health area, making possible positive impacts with results in improving quality in training and assistance provided to the community [11].

Thus, regarding of the teaching-learning relationship, Araújo [12] says that there must be a compromise between who teaches and who learns. It is necessary to desire to learn and to teach. The learning process is facilitated by the teacher figure. The student is the target for learning, a construction that is effective when built in partnership between those who teach and those who learn. "Learning is a process in which the student elaborates his knowledge through established interactions with the teacher" [13].

Based on the above considerations, the following research question emerged: Does the nursing student feel able to perform the Nursing Consultation for the patient from the Basic Nursing Network internship of the Undergraduate Nursing Course?

The following objectives were outlined to answer this question: To describe the students' learning about the Nursing Consultation Assistance Action; to understand the meaning of the Learning Action Nursing Consultation Action by the students who undertook the supervised internship in the Basic Attention Network.

Therefore, this study has an important contribution to the construction of knowledge, since the participation of the student can enable the elaboration of a Political Pedagogical Project whose educational planning is to offer the population a professional with an understanding of the real social and health demands.

\section{Method}

This is a qualitative, descriptive and exploratory study with an approach in the Sociological Phenomenology of Alfred Schutz (1899-1959), who was a lawyer, and he always worked with problems of social groups. He based his thinking on Max Weber's work with Comprehensive Sociology and drew on the phenomenology of Edmund Husserl. These references seek the understanding of inter-subjective relationships from the intentional action of a particular social group [14].

The following theoretical constructs were used to highlight the discussion of the results of this study: subjectivity, inter-subjectivity, knowledge baggage, the world of life, social action, the biographical situation [15]. 
Twenty students from a Higher Education Institution (IES) participated in the study in the Serrana Region - RJ of the Undergraduate Nursing Course. Students who had already completed the supervised internship in the Basic Attention Network in the $7^{\text {th }}$ period of the Undergraduate Nursing Course and who had received the evaluation grade were included, since the intention was to allow the participants to feel free to respond. Those who were unable or unwilling to respond for any reason, such as absence, illness, leave, and others were excluded.

For data collection, the phenomenological approach interview technique was used, with the following approximation questions: talk about how you learned to do the Nursing Consultation. What does this learning mean for you? What do you have in mind when developing the Nursing Consultation?

The interviews were recorded in MP3, previously scheduled with students according to their availability when they were in the Institution of Higher Education. They were held in a reserved room, from April to June 2015.

The students who accepted to participate in the study signed the Free and Informed Consent Term (TCLE) by Resolution 466/12. The students' statements were identified by the letter " $D$," together with letters of the alphabet according to the sequence in which the interviews were conducted to ensure their anonymity.

The interviews were carried out until the repetitions of the speeches when it was possible to perceive the inter-subjectivity of the subjects' actions. Data analysis was performed following the steps proposed in other studies: obtaining the testimonials; from the description of the lived; categorization through the analysis of these descriptions to capture the convergences of the reasons, so they can apprehend the meaning of the action; construction of the lived type of action, from the typical of the speech [16].

This research was approved by the Committee on Ethics and Research with Human Beings of the School of Nursing Anna Nery/UFRJ - RJ according to the opinion of 874.087 CAAE 37572914.0.0000.5238.

\section{Results}

Based on the understanding of individual experiences, Schutz $[17,18]$ found that living in a world of everyday life means living in an interactive engagement with others in complex networks of social relationships.

In this way, assuming that each human being carries an intention, it is understood that the action of the students who experience the Nursing Consultation is conscious and it is aimed at someone who is subject to their actions and constantly learning [15-14].

The biographical characteristics of the students show that they are between 18 and 37 years old. They are natural of the city where the Institution of Higher Education is located. Out of the twenty participants, 10 attended public high school and 10 private institutions. Thirteen students are nursing technicians. As for the financing of the Undergraduate Course, Eighteen students received funding and only two obtained funding from the Student Financing Fund (FIES).

In the context of this research, each student arrives at the Institution of Higher Education with a world of private life, full of feelings, experiences, expectations, difficulties, and, the pursuit of the dream to conquer a profession, having a motivation to be a nurse. With this, each student brings the individuality, a particular way to perceive the universe that is inserted, denominated like Subjectivity [19].

The student is supported by an Intentional project for the learning of his Social Action, which in this case is the Nursing Consultation. For the learning of this Action, students have Reasoned, called by Schutz $[13,14,20]$ as a reason for and the reason why. The reasons why refer to the contextualization of the project. Events are already completed. Ac- 
cessible to the observer. Moreover, the reasons for is the projection into the future of the intentional action of the student - the learning of the Nursing Consultation.

By knowing the Typical of the Action, it is possible to know the Meaning that this social group attributes to a phenomenon. This whole process happens in a face-to-face relationship: student - student; student - teacher; student - patient; student - health team [15].

From the testimony of the 20 students, it was possible to know important aspects that allowed the construction of four concrete categories of lived. They are Category 1: Use the theory and practice learning in the Nursing Consultation; Category 2: Seek to learn how to learn the duties of the nurse; Category 3: Build the learning process with satisfaction; Category 4: Learning how to learn the social action of the nurse to solving.

\section{Category 1. Use the theory and practice learning in the Nursing Consultation}

The students of the seventh period of the Undergraduate Nursing Course emphasize that they learned the Nursing Consultation in practice. They pointed out that there is a distancing between the transmission of theoretical knowledge and its application in the practice where it was possible to have experience of the Social Action of the nurse. They recognized the importance of the teacher side by side during the internship, valuing this learning for the professional life.

I learned in practice at the Outpatient School. I honestly did not know anything. It could be rather this contact with the practice. I did not even know how to make capillary glycemia because I am not a nursing technician. It was there at the Nursing Consultation that I learned: grief, about medications. Things have become real. I wanted more.
In fact, I learned in practice, going through the Nursing Consultation to the hypertensive and diabetic, prenatal care with pregnant women, women's health, child's health. I learned to perform in practice.

Db.

Schutz [13] used a term called sedimentation to define the result of activities of human consciousness, that is, a process that the elements of knowledge are integrated into the layers of knowledge previously acquired. In this sense, it is realized that there are always experiences of something, and all occur in the world of life.

I learned to do the Nursing Consultation through my teachers in the practical area, the internship. It was gratifying. It was a time of mistakes, correctness, studies, new knowledge. I learned by doing, joining concepts from theory to practice.

DC.

The practice was essential, to have the teacher there, to have the patient face to face with me, then yes I learned. I learned to be resolute, to identify problems. I learned in practice. The necessary techniques, I had everything there in my favor, with the teacher next to me.

It is identified that for the students, the practical activities during the supervised internship brings the possibility of fixing the contents learned in the classroom and affirm that the contact with the practice of the Nursing Consultation could happen during the Graduation. With this, it is possible to perceive that the presence of the teacher in the scenario of practice makes the theoretical contents applicable, real, practical for life of the future nurse professional.

At the moment of learning the Nursing Consultation, the student develops the practical skills 
of care and how a retro-feeder channel can use the concepts learned in the classroom and apply them to practical activity. To obtain better results in the learning process, it is opportune for teachers to provide students with pedagogical tools so in their singularity; they develop a conscious style of learning [21].

Learning to do was represented in this category because this pillar is related to the individual's ability to develop professional skills, to acquire codified knowledge, to understand the world in which he is inserted [22].

\section{Category 2. Seek to learn how to learn the duties of the nurse}

The speech of the student revealed to learn how to learn the attributions of the nurse during the Nursing Consultation. They said that during the course they had not yet understood the skills of the nurse, and during the process of learning the Nursing Consultation they verified their action as a professional. Regarding Schutz [15] as subjective meaning the form that each uses the efforts to reach the definition of his role within the community.

I took the whole college to find out what the nurse could do and there in the seventh period with the Nursing Consultation, My God!

Growth. Not just as a professional, but mainly as a person. I learned to have contact with the other. Understanding the nurse's role, knowing how far I can go. There was a lot - ripening. (tears) in all parts of people's lives.

In this way, Schutz $[13,15]$ shows that the world of life is given to the human being as something ready, but it can be modified through actions. Each constructs his world through the material aids and methods that are offered. It also emphasizes the participation of the person in his community. This meaning is related to the efforts to define their place in the subgroups that the individual participates. "The nurse is a professional qualified for human care, aiming to promote the quality of life and the maintenance of integrity." [23].

This learning for me was very important if it were not for the Nursing Consultation I would not be able to understand my duties as a nurse. The Nursing Consultation is only for the nurse. The Nursing Consultation is educational; it offers us autonomy. We have a Law.

Thus, when learning to be a nurse, the students understand what the duties of this professional are. They recognize the activity that is unique to this category. In this perspective, it is close to the nurses' performance in society and the social space he must occupy.

In this way, Nursing Consultation Learning can bring to the students the need to investigate each lived case, draw strategies, evaluate and re-evaluate them, in a continuous and infinite process of knowledge construction and reconstruction [24]

The Bloom Taxonomy [25] shows the cognitive domain as one that during the learning process students develop skills and attitudes to acquire new knowledge that stimulate constant intellectual development. It can be affirmed that this domain is developed during the practice of the Nursing Consultation.

\section{Category 3. Build the learning process with satisfaction}

The student during the Nursing Consultation learning felt part of the health team. When learning what is unique to the profession, he felt able to share the care. Creating, improvising, learning. It has a face-to-face relationship with the other. In this relationship between you and us, living with the patient, the peers, the health team, the teacher, sharing a relationship of familiarity, and being re- 
cognized by the patient as a professional, requested by the health team and by peers [15].

Nursing Consultation is all good. It is an achievement, it is good (laughs), very good. Sometimes we get a lot more than we give, and we learn a lot more than we teach. For me, this means accomplishment.

Very pleasurable, but we should have more practice. The theory is far from the practice, we arrive at the internship with fear, without knowing what it is real to know because in practice it is different, totally different. If this contact were before, it would be much better, much more advantageous. Learning how to learn by doing.

The student understands that he is part of the construction of the learning process, that when arriving at the internship he has fears, doubts, insecurities, but these feelings are replaced by satisfaction as they gain autonomy to teach, care and learn during the practice of Nursing Consultation.

Thus, they learned to live with each other, manage conflicts, share ideas and knowledge. The student develops skills to work as a team, uses the intuition, the ability to judge and keep the team united and balanced [10].

\section{Category 4. Learning how to learn the social action of the to solving}

When learning how to learn the Social Action of the nurse, the student realizes that care goes beyond complaints, he can promote health and prevent injuries, allowing how to learn to be, understanding the reason for being professional, developing mechanisms to "think, discern, have feelings and imagination that they need to develop the talents and remain as much as possible, owners of their destiny,,." [10]
I try to give resolution to the problems that the patient has. Focus with a more human look to be able to listen to the patient. Even when we will not solve everything but try to give as much assistance as possible, show what nursing is capable of, that we can solve problems, take a holistic look at the patient. Always take care of the best way possible.

\section{$\mathrm{Db}$.}

The human being is a social being who lives in a social world, of common sense, every day, also known as Levenswelt, these are expressions used by Schutz to define the expressions of the intersubjective world, experienced by the man in the natural attitude. [26]

\section{Discussion}

The speech of the participants of this study contributed to understanding the experience of the universe of learning how to learn the Social Action of the Nurse - Nursing Consultation. From then on, it is possible to devise strategies of teaching and learning, in a way that contemplates each student, considering their singularity.

The contextualization of this type of experience is in need of the students to have the presence of the teacher accompanying the teaching and learning process of the Nursing Consultation, not only from the seventh period and that the combination of theoretical and practical contents take place throughout the course Nursing Courses $[27,28]$

Given the results of this study and after finding the reasons to contextualize the reasons that are evidenced through the lived type [29] of the social group studied, it is noted that the assignment as a teacher can make a difference in the life of the future nurse professional. It is understood that being a teacher enables to meet the needs of those who want to learn and that each student presents his 
subjectivity, brings a baggage of knowledge and has his uniqueness in the world of life, which requires a unique planning to teach.

Thus, when returning the guiding question of this research: Does the nursing student feel apt to perform the Nursing Consultation for the patient from the internship in Nursing Course Basic Attention Network?

It can be affirmed that by describing the lived type of the social group of this study, the students feel able to perform the Nursing Consultation from the supervised internship in the Primary Care Network, learning theory and practice of the presence of the teacher, understanding the role of the nurse, and intending to carry out the Nursing Consultation to give resolution to the demands of the patient assisted.

Therefore, it was possible to reach the objectives outlined: to describe the students' learning about the Nursing Consultation Action; to understand the meaning of the Nursing Consultation Assistance Action learning by the students who undertook the supervised internship in the Basic Attention Network. They say that they learn concepts of anatomy, physiology, pharmacology, nursing fundamentals and others that contributed to nursing care, but they affirm that they learned to perform the Nursing Consultation in practice, where the theory becomes real, and they can fix the necessary contents. They emphasized that the theory is distant from practice and that nursing apprenticeship learning could occur before the seventh period and more often.

The meaning of Nursing Consultation learning was also revealed when the student recognized his role as a nurse because he was able to identify professional attribution in society. With the understanding that the Nursing Consultation learning phenomenon occurred in the practical scenario of supervised internship in the Basic Attention Network, and following the proposals of the Curricular Guidelines for the Undergraduate Nursing Course, when they determine that Higher Education Institutions stimulate the articulation of teaching, research, and assistance, it is suggested that the student reflect on the society that lives and has the possibility of transforming the context in which he/she lives. [30].

\section{Conclusion}

It is expected that the results of this study will be considered by the teaching managers, and will assist in the formulation and reformulation of Pedagogical Political Projects aimed at the training of nurses, valuing non-dissociated theory and practice, but as a foundation for the continuous construction of knowledge.

\section{References}

1. IOM (Institute of Medicine). The future of nursing: Leading Change, Advancing Health. Washington, DC: The National Academic Press. 2011.

2. Paim L, Trentini M, Silva DGV, Jochen AA. Desafios à Pesquisa em Enfermagem. Rev de Enf da Esc de Enfer Anna Nery. 2010 14(2): 386-390.

3. Mcewen M, Wills EM. Bases teóricas para enfermagem; tradução Ana Maria Thorell. 2 ${ }^{\mathrm{a}}$ Ed. Porto Alegre: Artmed, 2009.

4. Sousa ATO, Formiga NS, Oliveira SHS, Costa MML, Soares MJGO. Using the theory of meaningful leranig in nursing education. Rev Bras Enferm. 2015; 68(4):713-2

5. Brasil. Lei n. 7.498, de 25 de junho de 1986. Dispõe sobre a regulamentação do exercício da Enfermagem e dá outras providências. Brasil: 1986.

6. Jesus MCP, Capalbo C, Merighi MAB, Oliveira DM, Tocantins FR, Rodrigues BMRD, Ciuffo LL. A fenomenologia social de Afred Schutz e sua contribuição para enfermagem. Rev Esc Enferm USP 2013; 47(3):736-41

7. Oliveira SKP, Queiroz APO, Matos DPM, Mouro AF, Lima FET. Temas abordados na consulta de enfermagem: revisão integrativa da literatura. Rev Bras Enferm. 2012 jan-fev; 65(1): 155-61

8. ROSAS, Ann Mary Machado Tinoco Feitosa. O ensino da atividade assistencial - consulta de enfermagem: o típico da ação intencional. Tese de Doutorado. Rio de Janeiro: Universidade Federal do Rio de Janeiro Escola de Enfermagem Anna Nery EEAN/UFRJ, 2003 
9. ARAUJO, CRG. O significado da consulta de enfermagem no setor de radioterapia do Hospital Universitário Clementino Fraga Filho, na abordagem dos clientes e cuidadores. Dissertação Mestrado. Rio de Janeiro: Universidade Federal do Rio de Janeiro Escola de Enfermagem Anna Nery - EEAN/UFRJ, 2007

10. Delors J. Educação: um tesouro a descobrir. Portugal: UNESCO/ ASA, 1998.

11. Merighi MAB, Jesus MCP, Domingos SRF, Oliveira DM, Ito TN. Ensinar e aprender no campo clínico: perspectivas de docentes, enfermeiras e estudantes de enfermagem. Rev Bras Enferm. 2014 jul-ago; 67(4):505-11.

12. Araujo, CRG O ensinar e aprender na consulta de enfermagem entre clientes e enfermeiros no tratamento por braquiterapia ginecológica: uma abordagem fenomenológica. Tese de Doutorado. Rio de Janeiro: Universidade Federal do Rio de Janeiro Escola de Enfermagem Anna Nery - EEAN/UFRJ, 2013.

13. Cubas MR, Costa ERC, Marluce A, Nichiata LYI, Enembreck FS. Componentes of social learnig theory in a tool for theaching Nursing. Rev Bras Eferm. 2015; 68(5):623-9

14. Schutz A. Sobre fenomenologia e relações sociais. Org. H.R. Wagner. Petrópolis, RJ: Vozes; 2012.

15. Schutz A. El problema de la realidade social. Buenos Aires (AR): Amorrortu; 2008

16. Schutz A, Luckmann T. Las estructuras del mundo de la vida. Buenos Aires (AR): Amorrortu; 2009.

17. Saraiva RJ. A consulta de Enfermagem ao adulto idoso uma análise compreensiva como contribuição para o ensino. Dissertação Mestrado. Rio de janeiro: Universidade Federal do Rio de Janeiro. Escola de Enfermagem Anna Nery - EEAN/UFRJ - 2011

18. Rosa AF. Atividade assistencial, consulta de enfermagem em rede de atenção básica: uma análise compreensiva por discentes do curso de graduação em enfermagem. Dissertação de Mestrado. Rio de janeiro: Universidade Federal do Rio de Janeiro Escola de Enfermagem Anna Nery - EEAN/UFRJ; 2015.

19. Araujo $C R G$, Rosas AMMTF. A consulta de enfermagem para clientes e seus cuidadores no setor de radioterapia de hospital universitário. Rev Enferm UERJ 2008; 15(3): 364-9

20. Schutz A. Estudios sobre teoria social: escritos II. Buenos Aires: Amorrortu; 2003.

21. González F, Sáez K, Ramírez J. Perfiles de estilos de aprendizaje y rendimento académico em estudiantes de primer año de enfermeira. Rev Cien Enferm 2016 XXII (1) 87-99

22. Santos MF, Merighi MAB, Munoz LA. The experience of clinical nurses with nursing students: a phenomenological analysis. Rev Esc Enferm USP 2009; 43(3): 528- 34

23. Coelho MP, Menezes HF, Rosas AMMTF, Rosa AF, Pinto ACS, Saraiva RJ. O ensino do cuidado nos cursos de graduação em enfermagem do Brasil: revisão integrativa. Rev enferm UFPE 2016 fev 10(2):647-56
24. Rosa AF, Rosas AMMTF, Saraiva RJ, Pinto ACS, Shiraishi R. Experiência de um curso para gestantes. Quem ensina e quem aprende? Paraninfo Digital ano IX n22 2015. Disponível em: http://wwwindex-f.com/para/n22/524.php

25. Ferraz APCM, Belhot RV. Taxonomia de Bloom: revisão teórica e apresentação das adequações do instrumento para definição d objetivos instrucionais. Gest Prod São Carlos 2010 v.17, n.2, p. $421-431$

26. Carraro TE, Kempfer SS, Sebold LF, Oliveira MFV, Zeferino MT, Ramos DJS, et al. Cuidado de Saúde: uma aproximação teóricofilosófica com a fenomenologia. Cultura de los Cuidados, 2011 Jan-Abr; 29(1): 89-96

27. Araújo BBM, Rodrigues BMRD. O alojamento de mães de recém-nascidos prematuros: uma contribuição para ação de enfermagem. Esc Anna Nery Rev Enferm 2010 abr-jun; 14(2): 284-292

28. Becker GT. O significado da Consulta de Enfermagem para idosas atendidas em um Ambulatório Escola. Monografia. Petrópolis-RJ, Faculdade Arthur Sá Earp Neto. 2015

29. Schutz A. A fenomenologia e as relações sociais. Rio de Janeiro: Zahar; 1979.

30. Meleis Al. The stars are aligned; nurses must exercise their voice. Cul de los Cuid $20152^{\circ}$ quadrimestre ano XIX n42.

\section{Publish in International Archives of Medicine}

International Archives of Medicine is an open access journal publishing articles encompassing all aspects of medical science and clinical practice. IAM is considered a megajournal with independent sections on all areas of medicine. IAM is a really international journal with authors and board members from all around the world. The journal is widely indexed and classified Q2 in category Medicine. 